
3 Research Square
Preprints are preliminary reports that have not undergone peer review.
They should not be considered conclusive, used to inform clinical practice, or referenced by the media as validated information.

\title{
Surgical management and clinical outcomes of cerebellar liponeurocytomas-a report of 7 cases and a pooled analysis of individual patient data
}

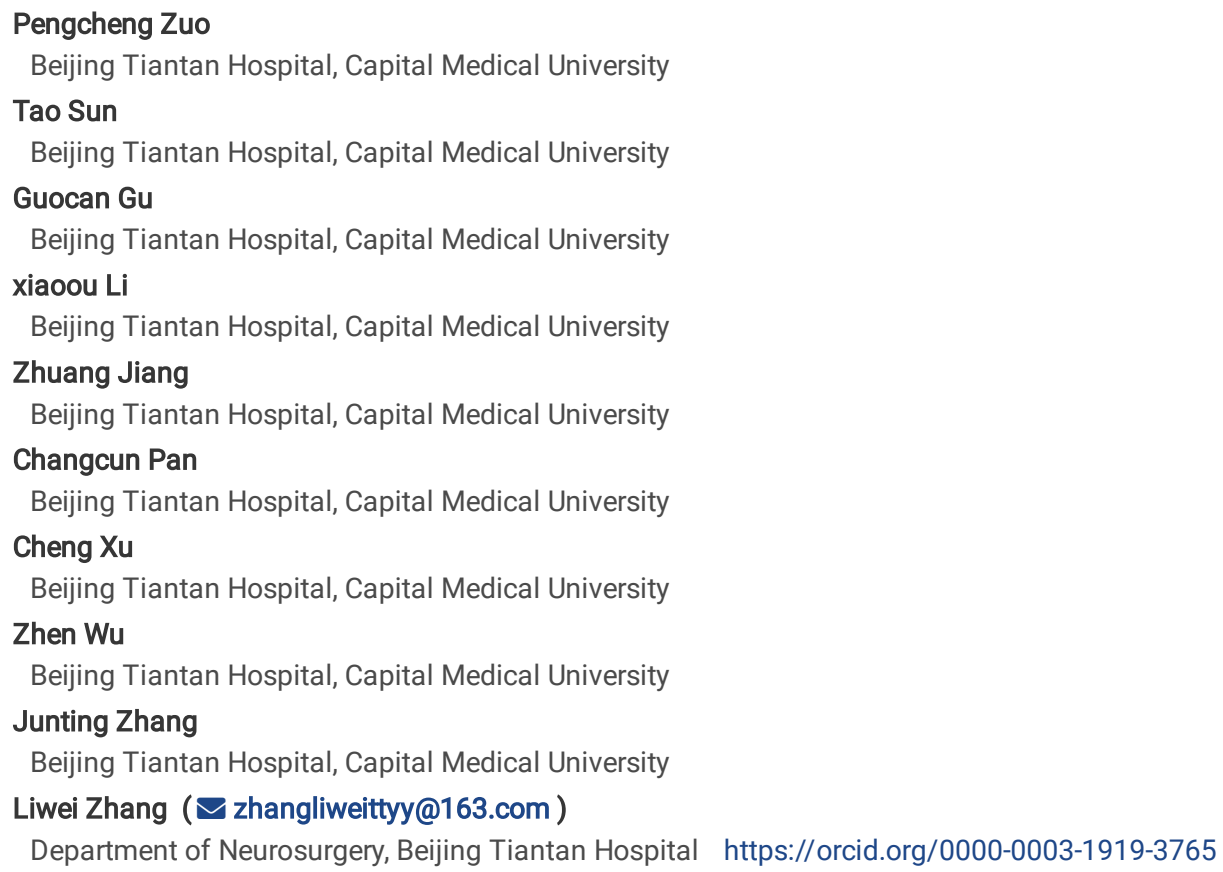




\section{Abstract Objective}

Cerebellar liponeurocytomas (CLPNs) are very rare. Limited studies described this disease and their treatment protocol remain unclear. To better understand the disease, we review the clinical features and outcomes, and propose a treatment protocol based on previously reported cases and cases from our institute.

\section{Methods}

The clinical data were obtained from 7 patients with pathologically confirmed CLPNs, who accepted surgical treatment in our institute between November 2011 and June 2021. We also reviewed the literature and 75 patients with CLPNs were identified between September 1993 and June 2021 . Risk factors for Progression-free survival (PFS) were evaluated in the pooled cohort.

\section{Results}

The authors' cohort included 4 males and 3 females with a mean age of $43.9 \pm 14.5$ (range: 29-64 years). 3 cases are located in lateral ventricle and 4 cases are located in cerebellum. All 7 cases achieved gross total resection (GTR) and radiotherapy was administered to 2 cases. After a mean follow-up of $44.9 \pm 44.4$ months, all patients remained well with no recurrence or death. For the reported 75 patients, there are 35 males and 40 females with a mean age of $46.2 \pm 13.6$ years (range: 6-77 years). Biopsy, gross total resection (GTR) and non-GTR were achieved in 1 (1.3\%), 50 (66.7\%), and 24 (32\%) patients, respectively. Radiotherapy was administered to 16 cases and chemotherapy was administered to only 1 case. After a mean follow-up of $47.5 \pm 51.5$ months, 3 patients died and tumor recurrence occurred in 17 patients. Multivariate Cox analysis revealed that non-GTR predicted a poor PFS ( $p=0.030$ ). Kaplan-Meier analysis showed that GTR was significantly associated with better PFS ( $p=0.0084)$. PFS rates at $1,5,10$ years were $92.7 \%, 78.0 \%, 23.8 \%$ respectively.

\section{Conclusions}

Cerebellar liponeurocytomas (CLPNs) are very rare brain tumors. Although they have favorable clinical prognosis, the recurrence is relatively high. GTR should be the first choice and close follow-up is necessary. Postoperative radiotherapy could not improve PFS in this study. A larger cohort is needed to verify our findings.

\section{Introduction}

Cerebellar liponeurocytoma (CLPN) is very rare. It was first reported in 1978 by Bechtel et al[7]. CLPN was firstly defined as a distinct entity according to the WHO 2000 classification of tumors of central nervous system[57]. In 2021, the lesion was categorized as a neuronal or neurocytic tumor and classified as WHO grade II tumor[45]. It usually occurred in adults and has a relatively favorable clinical outcome[44]. Although several cases have been reported previously, the treatment protocol still remained uncertain. Therefore, we retrospectively reviewed clinical data of 7 cases with CLPNs in our institute and reviewed the literature. We aimed to describe the clinical characteristics of CLPN, evaluate the risk factors for progression-free survival (PFS), and propose a treatment protocol for CLPN.

\section{Material And Methods}

We retrospectively reviewed the clinical data and radiographs of 7 cases with CLPNs who accepted surgical treatment at Beijing Tiantan Hospital between November 2011 and June 2021. The clinical data included age, sex, symptoms, duration of symptoms, tumor location, the extent of tumor resection, pathological results, radiotherapy and chemotherapy etc. The extent of tumor resection defined as gross total resection (GTR) and non-GTR based on preand postoperative MRIs. The pathological diagnosis of CLPNs was determined by the Department of Neuropathology at Beijing Neurosurgical Institute. This study was approved by the internal review board of Beijing Tiantan Hospital. For the literature review, we searched the PubMed database using the keywords "liponeurocytoma(s)" between September 1993 and June 2021 and a total of 75 cases were included. The risk factors were evaluated with univariate and multivariate Cox regression analysis of the pooled cases. The Kaplan-Meier method was used to determine the PFS differences with pvalues calculated from the log-rank test. Analyses were performed using SPSS statistical software with significance set at $p<0.05$.

\section{Results}

The authors' cohort include 4 (57.1\%) males and 3 (42.9\%) females, with a mean age of $43.9 \pm 14.5$ years (range: $29-64$ years). The mean duration of symptoms was $10.7 \pm 7.9$ months (range: $1-24$ months). Preoperative symptoms included headache (6/7, 85.7\%) and gait difficulty (1/7, $14.3 \%)$. 4 (57.1\%) cases were located in cerebellum and $3(42.9 \%)$ cases located in lateral ventricle. The family histories of all patients were unremarkable. On MRI, all 7 patients showed heterogeneous signals of T1WI and T2WI and heterogeneous enhancement was displayed in 6 (85.7\%) patients. Gross-total resection (GTR) were achieved in all patients. After a mean follow-up of $44.9 \pm 44.4$ months, all patients remained well with no recurrence or death. Immunohistochemically, Ki-67 index were relatively low for 6 available patients. The clinical data are summarized in Table 1. 
Table 1

Clinical characteristics of 7 cases with CLPNs

\begin{tabular}{|c|c|c|c|c|c|c|c|c|c|c|c|c|}
\hline Case & Sex & Age & symptoms & $\begin{array}{l}\text { Duration } \\
\text { of } \\
\text { symptoms } \\
\text { (months) }\end{array}$ & Location & Treatment & $\begin{array}{l}\text { Ki- } \\
67 \\
(\%)\end{array}$ & Multifocality & Recurrence & Outcome & $\begin{array}{l}\text { PFS } \\
\text { (months) }\end{array}$ & $\begin{array}{l}\text { FU } \\
\text { (months) }\end{array}$ \\
\hline 1 & $\mathrm{~F}$ & 48 & Headache & 18 & Cerebellum & GTR & $<5$ & No & No & Alive & 120.8 & 120.8 \\
\hline 2 & $M$ & 29 & Headache & 1 & $\begin{array}{l}\text { Lateral } \\
\text { ventricle }\end{array}$ & GTR & 5 & No & No & Alive & 83.4 & 83.4 \\
\hline 3 & $\mathrm{~F}$ & 64 & Headache & 24 & Cerebellum & GTR+RT & 7.5 & No & No & Alive & 57.3 & 57.3 \\
\hline 4 & $\mathrm{~F}$ & 30 & Headache & 12 & $\begin{array}{l}\text { Lateral } \\
\text { ventricle }\end{array}$ & GTR & 7 & No & No & Alive & 29.6 & 29.6 \\
\hline 5 & $M$ & 57 & $\begin{array}{l}\text { Gait } \\
\text { difficulty }\end{array}$ & 8 & Cerebellum & $\mathrm{GTR}+\mathrm{RT}$ & 5 & No & No & Alive & 13.1 & 13.1 \\
\hline 6 & M & 50 & Headache & 6 & Cerebellum & GTR & 5.5 & No & No & Alive & 5.3 & 5.3 \\
\hline 7 & $M$ & 29 & Headache & 6 & $\begin{array}{l}\text { Lateral } \\
\text { ventricle }\end{array}$ & GTR & NA & No & No & Alive & 4.6 & 4.6 \\
\hline
\end{tabular}

For the literature review, 75 cases of CLPNs were identified (Table 2). Among them, 35 cases were males and 40 cases were females with a mean age of 46.2 \pm 13.6 years (range: 6-77 years). On Magnetic Resonance Imaging (MRI), 58 cases (77.3\%) were located in infratentorial region (including cerebellum, CPA area and fourth ventricle) and 17 cases (22.7\%) located in supratentorial region (including lateral ventricle and frontal lobe). Biopsy, gross total resection (GTR) and non-GTR were achieved in 1 (1.3\%), 50 (66.7\%), and 24 (32\%) patients, respectively. Radiotherapy was administered to 16 cases and chemotherapy was administered to only 1 case. After a mean follow-up of $47.2 \pm 50.4$ months, tumor recurrence occurred in 17 (26.6\%) patients (Table 3 ). 
Table 2

Clinical data of 75 cases with cerebellar liponeurocytoma from September 1993 to June 2021

\begin{tabular}{|c|c|c|c|c|c|c|c|c|c|}
\hline Authors and year & $\begin{array}{l}\text { Sex/age } \\
\text { (years) }\end{array}$ & Location & Multifocality & $\begin{array}{l}\text { Ki-67 } \\
(\%)\end{array}$ & Treatment & Recurrence & Outcome & $\begin{array}{l}\text { PFS } \\
\text { (months) }\end{array}$ & $\begin{array}{l}\text { FU } \\
\text { (months) }\end{array}$ \\
\hline $\begin{array}{l}\text { Hirono et al., } \\
2021[34]\end{array}$ & $\mathrm{F} / 44$ & $\begin{array}{l}\text { Cerebellum, third and } \\
\text { fourth ventricle }\end{array}$ & Yes & 2 & Non-GTR & Yes & Alive & 7 & 7 \\
\hline $\begin{array}{l}\text { Al-Umran et al., } \\
2021[4]\end{array}$ & $M / 24$ & Lateral ventricle & No & 10 & $\mathrm{GTR}+\mathrm{RT}$ & No & Alive & 12 & 12 \\
\hline $\begin{array}{l}\text { Abuzneid et al., } \\
\text { 2021[1] }\end{array}$ & $\mathrm{F} / 50$ & Cerebellum & No & NA & GTR & No & Alive & 1 & 1 \\
\hline $\begin{array}{l}\text { Deora et al., } \\
2019[21]\end{array}$ & $\mathrm{M} / 55$ & Cerebellum & No & 4.5 & Non-GTR & No & Alive & 48 & 48 \\
\hline $\begin{array}{l}\text { Hamzaoglu et al., } \\
2018[32]\end{array}$ & $F / 55$ & Cerebellum & No & 2 & GTR & No & Alive & - & - \\
\hline $\begin{array}{l}\text { Gembruch et al., } \\
2018[26]\end{array}$ & $M / 39$ & Cerebellum & No & 2 & GTR & No & Alive & 15 & 15 \\
\hline $\begin{array}{l}\text { Chiaramonte et al., } \\
\text { 2018[17] }\end{array}$ & $\mathrm{F} / 35$ & Cerebellum & No & 6 & GTR & No & Alive & 48 & 48 \\
\hline Cai et al., 2018[14] & $\mathrm{M} / 11$ & Frontal lobe & No & 1.5 & GTR & No & Alive & 74 & 74 \\
\hline $\begin{array}{l}\text { Börekci et al., } \\
\text { 2018[11] }\end{array}$ & $F / 62$ & Lateral ventricle & No & NA & GTR & No & Alive & 6 & 6 \\
\hline $\begin{array}{l}\text { Ben Nsir et al., } \\
\text { 2018[10] }\end{array}$ & $F / 24$ & Lateral ventricle & No & 3 & GTR & No & Alive & 12 & 12 \\
\hline \multirow[t]{2}{*}{ Xu et al., 2017[69] } & $M / 29$ & Lateral ventricle & No & 3.5 & GTR & No & Alive & 24 & 24 \\
\hline & $F / 48$ & Cerebellum & No & 1.5 & GTR & No & Alive & 60 & 60 \\
\hline \multirow[t]{3}{*}{ Xu et al., 2017[68] } & $F / 49$ & Cerebellum & No & 1 & GTR & NA & NA & NA & NA \\
\hline & $\mathrm{F} / 45$ & Cerebellum & No & $<1$ & GTR & No & Alive & 54 & 54 \\
\hline & $M / 29$ & Lateral ventricle & No & 5 & GTR & No & Alive & 17 & 17 \\
\hline $\begin{array}{l}\text { Tucker et al., } \\
\text { 2017[65] }\end{array}$ & $F / 41$ & Cerebellum & No & 4 & GTR & NA & NA & NA & NA \\
\hline $\begin{array}{l}\text { Sivaraju et al., } \\
\text { 2017[61] }\end{array}$ & $M / 37$ & Cerebellum & Yes & 6 & $\begin{array}{l}\text { Non- } \\
\text { GTR+RT }\end{array}$ & No & Alive & 24 & 24 \\
\hline $\begin{array}{l}\text { Hermann et al., } \\
\text { 2017[33] }\end{array}$ & $\mathrm{F} / 77$ & Cerebellum & No & 12 & GTR & No & Alive & 24 & 24 \\
\hline $\begin{array}{l}\text { Wolf et al., } \\
\text { 2016[67] }\end{array}$ & $\mathrm{F} / 37$ & Cerebellum & No & $<1$ & Non-GTR & NA & NA & NA & NA \\
\hline $\begin{array}{l}\text { Pikis et al., } \\
\text { 2016[55] }\end{array}$ & $\mathrm{F} / 72$ & Cerebellum & No & 12.5 & GTR & No & Alive & 36 & 36 \\
\hline $\begin{array}{l}\text { Nzegwu et al., } \\
2016[47]\end{array}$ & $F / 6$ & Cerebellum & No & NA & GTR & No & Alive & - & - \\
\hline $\begin{array}{l}\text { Takami et al., } \\
\text { 2015[64] }\end{array}$ & $M / 59$ & Cerebellum & No & 2 & Non-GTR & No & Alive & 24 & 24 \\
\hline $\begin{array}{l}\text { Scoppetta et al., } \\
2015[60]\end{array}$ & $\mathrm{M} / 42$ & Cerebellum & Yes & NA & Biopsy & NA & NA & NA & NA \\
\hline $\begin{array}{l}\text { Radke et al., } \\
\text { 2015[56] }\end{array}$ & $\mathrm{F} / 59$ & Cerebellum & No & 3 & Non-GTR & Yes & Alive & 180 & 204 \\
\hline $\begin{array}{l}\text { Kakkar et al., } \\
\text { 2015[39] }\end{array}$ & M/35 & Cerebellum & No & 3.5 & GTR & No & Alive & - & - \\
\hline $\begin{array}{l}\text { Ruiz Ginés r et al., } \\
\text { 2014[59] }\end{array}$ & $M / 33$ & Lateral ventricle & No & $<1$ & GTR & NA & NA & NA & NA \\
\hline $\begin{array}{l}\text { Oudrhiri et al., } \\
\text { 2014[49] }\end{array}$ & $F / 64$ & Cerebellum & No & $<1$ & Non-GTR & No & Alive & 24 & 24 \\
\hline $\begin{array}{l}\text { Karabagli et al., } \\
2014[40]\end{array}$ & $\mathrm{M} / 34$ & Lateral ventricle & No & 1.5 & GTR & No & Alive & 24 & 24 \\
\hline
\end{tabular}




\begin{tabular}{|c|c|c|c|c|c|c|c|c|c|}
\hline Authors and year & $\begin{array}{l}\text { Sex/age } \\
\text { (years) }\end{array}$ & Location & Multifocality & $\begin{array}{l}\text { Ki-67 } \\
(\%)\end{array}$ & Treatment & Recurrence & Outcome & $\begin{array}{l}\text { PFS } \\
\text { (months) }\end{array}$ & $\begin{array}{l}\text { FU } \\
\text { (months) }\end{array}$ \\
\hline $\begin{array}{l}\text { Ben Nsir et al., } \\
2014[9]\end{array}$ & $F / 59$ & Cerebellum & No & 3 & GTR & No & Alive & 18 & 18 \\
\hline $\begin{array}{l}\text { Pelz et al., } \\
\text { 2013[54] }\end{array}$ & $F / 54$ & Cerebellum & Yes & NA & Non-GTR & Yes & Alive & 24 & 48 \\
\hline Dey et al., 2013[22] & $\mathrm{F} / 30$ & Cerebellum & No & 3 & Non-GTR & Yes & Alive & 6 & 6 \\
\hline $\begin{array}{l}\text { Beizig et al., } \\
\text { 2013[8] }\end{array}$ & $F / 45$ & Cerebellum & No & NA & GTR & No & Alive & 18 & 18 \\
\hline $\begin{array}{l}\text { Guan et al., } \\
2012[30]\end{array}$ & $\mathrm{M} / 50$ & Cerebellum & No & NA & GTR & NA & NA & NA & NA \\
\hline $\begin{array}{l}\text { Chung et al., } \\
2012[18]\end{array}$ & $\mathrm{M} / 49$ & Cerebellum & No & 13.68 & $\begin{array}{l}\text { Non-GTR } \\
+\mathrm{RT}\end{array}$ & No & Alive & 12 & 12 \\
\hline \multirow{2}{*}{$\begin{array}{l}\text { Anghileri et al., } \\
2012[6]\end{array}$} & $\mathrm{F} / 40$ & Cerebellum & No & 1.5 & GTR & Yes & Alive & 96 & 132 \\
\hline & $F / 59$ & Cerebellum & No & 1.5 & Non-GTR & Yes & Alive & 15 & 120 \\
\hline $\begin{array}{l}\text { Gupta et al., } \\
2011[31]\end{array}$ & $\mathrm{F} / 45$ & Lateral ventricle & No & 3 & GTR & NA & NA & NA & NA \\
\hline $\begin{array}{l}\text { den Hollander et } \\
\text { al., 2011[20] }\end{array}$ & $M / 43$ & Lateral ventricle & No & NA & GTR & NA & NA & NA & NA \\
\hline \multirow{4}{*}{$\begin{array}{l}\text { Chakraborti et al., } \\
2011[15]\end{array}$} & $M / 36$ & Lateral ventricle & No & $<1$ & GTR & Yes & Alive & 112 & 136 \\
\hline & $\mathrm{M} / 30$ & Lateral ventricle & No & $<1$ & GTR & NA & NA & NA & NA \\
\hline & $M / 32$ & Lateral ventricle & No & $<1$ & GTR & NA & NA & NA & NA \\
\hline & $\mathrm{F} / 45$ & Cerebellum & No & $<1$ & GTR & NA & NA & NA & NA \\
\hline $\begin{array}{l}\text { Pankaj et al., } \\
\text { 2010[51] }\end{array}$ & M/35 & Lateral ventricle & No & NA & GTR & No & Alive & - & - \\
\hline $\begin{array}{l}\text { Patel et al., } \\
\text { 2009[53] }\end{array}$ & $\mathrm{F} / 40$ & Cerebellum & No & NA & GTR & No & Alive & 36 & 36 \\
\hline $\begin{array}{l}\text { Pasquale et al., } \\
2009[52]\end{array}$ & $M / 64$ & Cerebellum & No & 15 & GTR & Yes & Alive & 42 & 90 \\
\hline $\begin{array}{l}\text { Limaiem et al., } \\
2009[43]\end{array}$ & $\mathrm{M} / 42$ & Cerebellum & No & 2 & GTR & Yes & Alive & 120 & 132 \\
\hline $\begin{array}{l}\text { Châtillon et al., } \\
2009[16]\end{array}$ & $F / 42$ & Cerebellum & No & 10 & GTR+RT & No & Alive & 36 & 36 \\
\hline $\begin{array}{l}\text { Kuchelmeister et } \\
\text { al., 2006[42] }\end{array}$ & $M / 35$ & Lateral ventricle & No & NA & Non-GTR & NA & NA & NA & NA \\
\hline $\begin{array}{l}\text { Owler et al., } \\
2005[50]\end{array}$ & $M / 34$ & Fourth ventricle & No & NA & GTR+RT & No & Alive & 8 & 8 \\
\hline $\begin{array}{l}\text { Buccoliero et al., } \\
2005[12]\end{array}$ & $M / 64$ & Cerebellum & No & $\nabla 10$ & GTR+RT & No & Alive & 5 & 5 \\
\hline Aker et al., 2005[2] & $F / 49$ & Cerebellum & No & $<1$ & $\begin{array}{l}\text { Non-GTR } \\
+\mathrm{RT}\end{array}$ & Yes & Dead & 2 & 19 \\
\hline $\begin{array}{l}\text { Valéry et al., } \\
\text { 2004[66] }\end{array}$ & $\mathrm{F} / 74$ & Cerebellum & No & 5 & GTR+RT & No & Alive & 12 & 12 \\
\hline $\begin{array}{l}\text { Rajesh et al., } \\
2003[58]\end{array}$ & $\mathrm{M} / 30$ & Lateral ventricle & No & NA & Non-GTR & - & Dead* & - & - \\
\hline $\begin{array}{l}\text { Kachhara et al., } \\
2003[38]\end{array}$ & $F / 62$ & Cerebellum & No & NA & GTR & NA & NA & NA & NA \\
\hline $\begin{array}{l}\text { Jenkinson et al., } \\
2003[37]\end{array}$ & $F / 51$ & Cerebellum & No & 3 & $\begin{array}{l}\text { Non-GTR } \\
+\mathrm{RT}\end{array}$ & Yes & Alive & 12 & 15 \\
\hline $\begin{array}{l}\text { Fung et al., } \\
2003[25]\end{array}$ & $F / 56$ & Cerebellum & No & NA & Non-GTR & No & Alive & 6 & 6 \\
\hline
\end{tabular}




\begin{tabular}{|c|c|c|c|c|c|c|c|c|c|}
\hline Authors and year & $\begin{array}{l}\text { Sex/age } \\
\text { (years) }\end{array}$ & Location & Multifocality & $\begin{array}{l}\mathrm{Ki}-67 \\
(\%)\end{array}$ & Treatment & Recurrence & Outcome & $\begin{array}{l}\text { PFS } \\
\text { (months) }\end{array}$ & $\begin{array}{l}\text { FU } \\
\text { (months) }\end{array}$ \\
\hline $\begin{array}{l}\text { Elshihabi et al., } \\
\text { 2003[24] }\end{array}$ & $\mathrm{F} / 45$ & Cerebellum & No & $<2.5$ & $\begin{array}{l}\text { Non-GTR } \\
+\mathrm{RT}+\mathrm{CT}\end{array}$ & No & Alive & 36 & 36 \\
\hline $\begin{array}{l}\text { Akhaddar et al., } \\
\text { 2003[3] }\end{array}$ & $\mathrm{F} / 43$ & Cerebellum & No & NA & GTR & No & Alive & 16 & 16 \\
\hline $\begin{array}{l}\text { Montagna et al., } \\
\text { 2002[46] }\end{array}$ & $F / 53$ & Cerebellum & No & NA & $\begin{array}{l}\text { Non-GTR } \\
+\mathrm{RT}\end{array}$ & NA & NA & NA & NA \\
\hline $\begin{array}{l}\text { Cacciola et al., } \\
\text { 2002[13] }\end{array}$ & $\mathrm{M} / 61$ & Cerebellum & No & NA & GTR & No & Alive & 12 & 12 \\
\hline $\begin{array}{l}\text { Taddei et al., } \\
\text { 2001[63] }\end{array}$ & $M / 61$ & Cerebellum & No & NA & GTR & No & Alive & 6 & 6 \\
\hline $\begin{array}{l}\text { Jackson et al., } \\
2001[36]\end{array}$ & $M / 66$ & Cerebellum & No & 3 & $\mathrm{GTR}+\mathrm{RT}$ & NA & NA & NA & NA \\
\hline $\begin{array}{l}\text { George et al., } \\
\text { 2001[28] }\end{array}$ & $F / 59$ & Lateral ventricle & No & 5.8 & Non-GTR & Yes & Alive & 67 & 67 \\
\hline \multirow{2}{*}{$\begin{array}{l}\text { Alkadhi et al., } \\
2001[5]\end{array}$} & $M / 38$ & Cerebellum & No & NA & GTR & No & Alive & 15 & 15 \\
\hline & $M / 53$ & Cerebellum & No & NA & Non-GTR & Yes & Alive & 108 & 180 \\
\hline $\begin{array}{l}\text { Orlandi et al., } \\
\text { 1997[48] }\end{array}$ & $M / 55$ & Cerebellum & No & NA & GTR & No & Alive & 8 & 8 \\
\hline \multirow[t]{3}{*}{$\begin{array}{l}\text { Soylemezoglu et } \\
\text { al., 1996[62] }\end{array}$} & $\mathrm{F} / 48$ & Cerebellum & No & $<5$ & $\begin{array}{l}\text { Non-GTR } \\
+\mathrm{RT}\end{array}$ & No & Alive & 42 & 42 \\
\hline & $M / 53$ & CPA area & No & $<5$ & GTR & Yes & Alive & 132 & 132 \\
\hline & $F / 59$ & CPA area & No & $<5$ & GTR+RT & No & Alive & 60 & 60 \\
\hline \multirow{3}{*}{$\begin{array}{l}\text { Giangaspero et al., } \\
\text { 1996[29] }\end{array}$} & $M / 37$ & Cerebellum & No & $<1$ & GTR & Yes & Dead* & 120 & 132 \\
\hline & $M / 36$ & Cerebellum & No & $<1$ & GTR & Yes & Alive & 120 & 180 \\
\hline & $\mathrm{F} / 57$ & Cerebellum & No & $<1$ & $\begin{array}{l}\text { Non-GTR } \\
+\mathrm{RT}\end{array}$ & No & Alive & 24 & 24 \\
\hline $\begin{array}{l}\text { Ellison et al., } \\
\text { 1993[23] }\end{array}$ & $\mathrm{F} / 50$ & Cerebellum & No & $<1$ & GTR & NA & NA & NA & NA \\
\hline \multirow{2}{*}{$\begin{array}{l}\text { Davis et al., } \\
\text { 1993[19] }\end{array}$} & $\mathrm{F} / 49$ & Cerebellum & No & NA & Non-GTR & Yes & Alive & 60 & 60 \\
\hline & $M / 53$ & Cerebellum & No & NA & $\begin{array}{l}\text { Non- } \\
\text { GTR+RT }\end{array}$ & NA & Dead* & - & 6 \\
\hline
\end{tabular}


Table 3

Summary of clinical characteristics of cerebellar liponeurocytoma from literature and our institute

\begin{tabular}{|lllll|}
\hline Variable & \multicolumn{2}{c}{ Reported cases (n=75) } & Current series & Overall \\
\cline { 2 - 4 } & No. of Available cases & Value & \\
\hline Mean age, years & 75 & $46.2 \pm 13.6$ & $43.9 \pm 14.5$ & $46.0 \pm 13.6$ \\
\hline Sex (M/F) & 75 & $35 / 40$ & $4 / 3$ & $39 / 43$ \\
\hline Supratentorial/Infratentorial & 75 & $17 / 58$ & $3 / 4$ & $20 / 62$ \\
\hline Multifocality & 75 & 4 & 0 & 4 \\
\hline GTR & 75 & $50(66.7 \%)$ & $7(100 \%)$ & $57(76 \%)$ \\
\hline Radiotherapy & 75 & $16(21.3 \%)$ & $2(28.6 \%)$ & $18(22.0 \%)$ \\
\hline Chemotherapy & 75 & $1(1.3 \%)$ & 0 & $1(1.2 \%)$ \\
\hline Mean PFS, months & 53 & $40.0 \pm 40.7$ & $44.9 \pm 44.4$ & $40.6 \pm 40.8$ \\
\hline Mean FU, months & 54 & $47.5 \pm 51.5$ & $44.9 \pm 44.4$ & $47.2 \pm 50.4$ \\
\hline Recurrence & 57 & $17(29.8 \%)$ & 0 & $17(26.6 \%)$ \\
\hline Death & 59 & $4(6.8 \%)$ & 0 & $4(6.1 \%)$ \\
\hline Values are presented as the number of patients (\%), and mean values are presented as mean \pm SD. \\
\hline
\end{tabular}

The mean follow-up in the pooled cohort (including 7 cases from our institute and 53 cases from the literature) was $47.2 \pm 50.4$ months. PFS rates at 1,5 , 10 years were $92.7 \%, 78.0 \%, 23.8 \%$ respectively. The univariate Cox regression analysis showed that GTR $(p=0.015)$ had significantly prolonged PFS than non-GTR. Other risk factors, including age $(p=0.800)$, sex $(p=0.325)$, tumor location $(p=0.782)$ and radiotherapy $(p=0.708)$, were not significant. Then we added sex, GTR and radiotherapy to the multivariate cox analysis. GTR ( $p=0.030)$ was the only risk factor to predict a better PFS (Table 4). Kaplan-Meier analysis showed that compared to non-GTR (median PFS: 67 months), GTR (median PFS: 120 months) was significantly associated with better PFS $(p=0.0084)$ and radiotherapy $(p=0.7068)$ could not predict a better PFS (Figure $3 A, B)$. For non-GTR group, radiotherapy was not associated with better PFS $(p=0.9197)$ (Figure 3C).

Table 4

Cox regression model for risk factors predicting PFS

\begin{tabular}{|c|c|c|c|c|c|c|}
\hline \multirow[t]{2}{*}{ Variable } & \multirow[t]{2}{*}{ Number of patients } & \multirow[t]{2}{*}{ Recurrence (\%) } & \multicolumn{2}{|l|}{ Univariate Analysis } & \multicolumn{2}{|l|}{ Multivariate Analysis } \\
\hline & & & $\mathrm{HR}(95 \% \mathrm{Cl})$ & $P$ value & $\mathrm{HR}(95 \% \mathrm{Cl})$ & $P$ value \\
\hline Overall & 60 & $17(28.3)$ & & & & \\
\hline \multicolumn{7}{|l|}{ Age } \\
\hline Age $\leq 45$ & 27 & $7(25.9)$ & Reference & & & \\
\hline Age $₫ 45$ & 33 & $10(30.3)$ & $1.140(0.412-3.155)$ & 0.800 & & \\
\hline \multicolumn{7}{|l|}{ Sex } \\
\hline Female & 33 & $10(30.3)$ & Reference & & Reference & \\
\hline Male & 27 & $7(25.9)$ & $0.600(0.217-1.660)$ & 0.325 & $1.007(0.327-3.106)$ & 0.990 \\
\hline \multicolumn{7}{|l|}{ Location } \\
\hline Supratentorial & 12 & $2(16.7)$ & Reference & & & \\
\hline Infratentorial & 48 & $15(31.3)$ & $1.241(0.268-5.744)$ & 0.782 & & \\
\hline \multicolumn{7}{|l|}{ GTR } \\
\hline Yes & 40 & 7 (17.5) & Reference & & Reference & \\
\hline No & 20 & $10(50)$ & $0.285(0.103-0.787)$ & $0.015^{\star}$ & $0.286(0.092-0.887)$ & $0.030 *$ \\
\hline \multicolumn{7}{|l|}{ Radiotherapy } \\
\hline Yes & 15 & $2(13.3)$ & Reference & & Reference & \\
\hline No & 45 & $15(33.3)$ & $1.364(0.268-6.935)$ & 0.708 & $1.115(0.215-5.788)$ & 0.897 \\
\hline
\end{tabular}




\section{Illustrative Cases}

\section{Case 3}

A 64-year-old female presented with a 2-year history of dizziness and headache. Neurological examination revealed no neurological dysfunction. MR scans revealed a solid mass involving right side of cerebellum with heterogeneous signals on both T1WI and T2WI (Figure 1A and B). Contrast-enhanced MRI showed significant heterogeneous enhancement of the tumor (Figure 1C). A right suboccipital paramedian approach was performed. During surgery, the tumor was gray-red with soft texture and medium blood supply. There was a clear boundary between the surrounding brain tissue and the mass. Pathological examination revealed that some fat foci are dispersed within atypical tumor cells (Figure $1 \mathrm{G}$ ). Immunohistochemistry revealed the tumor cells were positive for Syn, NeuN, MAP2, GFAP, ATRX and negative for olig-2 and IDH1. The Ki-67 index was approximately $7.5 \%$. A cerebellar liponeurocytoma was confirmed by pathologists. Postoperative MRI showed the tumor was completely resected (Figure 1D-F). The postoperative course was uneventful and the patient was discharged 8 days after surgery. She was uneventful for the following 57.3 months until the last telephone interview.

\section{Case 4}

A 30-year-old woman experienced a surgical resection of a mass located at lateral ventricle at other hospital 1 year ago. The tumor was not resected totally and she came to our hospital for further treatment. Neurological examination revealed weakness of left limb. MR scans revealed a cystic-solid mass involving lateral ventricle with heterogeneous signals of both T1WI and T2WI (Figure 2A, B). Contrast-enhanced MRI showed no enhancement (Figure 2C). A right frontal approach was performed and boundary between the tumor and the surrounding brain tissue was not clear. Ultimately, the patient achieved gross total resection. Pathological examination revealed a cerebellar liponeurocytoma (Figure $2 \mathrm{G}$ ). Postoperative MRI showed no residue of the tumor (Figure 2D-F). After 29.6 months, no evidence of tumor recurrence was observed.

\section{Discussion}

Cerebellar liponeurocytoma (CLPN) is a rare tumor that is characterized by well-differentiated histological features and a favorable clinical prognosis[1, 41]. Due to the rarity, most papers focused on describing the clinical features of CLPN, but few papers discussed treatment protocol for the rare lesion. Here, we reported the largest cohort of 7 cases from our institute and reviewed 75 cases from the literature, and try to verify adverse factors for PFS.

As its name implies, cerebellar liponeurocytoma is mainly located at the cerebellum and it is uncommon for the lesion to originate within the lateral ventricle[4]. Of the pooled analysis, $24 \%$ (20/82) cases of CLPN involved lateral ventricle, this entity should be considered as solely liponeurocytoma. There is no significant gender predominance for CLPN in this study, however, for supratentorial liponeurocytoma, the male-to-female ratio was 3:1, with an obvious male predilection, for infratentorial liponeurocytoma, the male-to-female ratio was 2.4:3.8, with a female predilection. The brain tumor often affected adults and occasionally involved children, only 2 patients below 20 years old were reported previously[14, 47]. The tumors were usually solitary, but multifocal lesions were also reported[34, 54, 60, 61].

Radiologically, Gembruch et al analyzed the features of MRI and found that hypointense (55\%) and isointense (27.5\%) on T1-weighted images and hyperintense (88.25\%) on T2-weighted images[27]. Most cases can be observed a heterogeneous contrast enhancement after administration of contrast agent[27]. The fat in CLPN can be observed on CT as a hypodense lesion. MRI imaging usually shows a hyperintense signal on T1WI and the signal often get inverted in fat-suppressed images[21]. According to previous studies, $11 \mathrm{C}$-methionine in positron emission tomography (Met-PET) showed that Met uptake values were relatively high (Tmax/Nave: 3.2, 2.7), which may help establish a preoperative diagnosis of CLPN[34, 64].

Histologically, CLPN was composed of monotonous small round tumor cells and lipomatous cells[68]. Mitosis is rare or absent. The Ki-67 or MIB-1 index in the majority of reported cases was low $[49,64,67]$, which was consistent with our findings. Kakkar et al pointed out the lipomatous cells were caused by lipidization of the neurocytic cells other than true adipocytic differentiation[39]. Although most CLPNs reveal benign histological features, several cases with atypical features have been described[28, 50]. In the study, the Ki-67 index was relatively high for 5 cases ( $\geq 10 \%)$ and no case experienced a relapse. Due to the rarity of the disease, genomic profiles of CLPNs remained uncertain. Horstmann performed DNA sequencing for 20 CLPNs and found that TP53 missense mutations were the most common genetic alterations with a $20 \%$ frequency[35]. Anghileri et al pointed that FABP4 maybe a candidate marker for CLPNs, which is significantly overexpressed in the tumor[6].

The clinical prognosis of CLPN is generally satisfactory. Among the available 66 cases (including 59 cases from the literature and 7 cases from our institute), only 4 patients died and the mortality rate was $6.1 \% .3$ of them died of postoperative intracranial hemorrhage or pneumonia and only one patient may die from a tumor-related event. However, recurrence of CLPN is relatively high, available 64 cases (including 57 cases from the literature and 7 cases from our institute), 17 cases (26.6\%) suffered tumor recurrence. In previous studies, optimum treatment modality was considered to be totally surgical resection[21]. We performed a multivariate Cox analysis and the results revealed that GTR had significantly prolonged PFS ( $p=0.030)$. Kaplan-Meier analysis showed that compared to non-GTR, GTR has a 53-month longer PFS. It is noting that 9 patients suffered relatively early tumor recurrence (PFS within 67 months) and 8 (88.9\%) of them accepted non-GTR previously. 8 patients suffered latterly recurrence (PFS beyond 8 years) and only 2 (25\%) cases accepted non-GTR. We speculate that GTR could prevent the early recurrence of CLPN but had limited benefit on its long-term recurrence. Some studies believe that postoperative radiotherapy decrease the tumor recurrence[21, 27], but of our pooled analysis, there is no statistical difference of tumor recurrence with or without radiotherapy. Kaplan-Meier curve also showed that Radiotherapy did not significantly prolonged PFS. For the non-GTR group, radiotherapy still did not show a better PFS. Based on these facts, we recommend GTR as CLPN best treatment and close follow-up should be performed, 
although GTR was achieved. However, when CLPN showed atypical histological features, radiotherapy should be advised. In recent articles, Wolf et al and Pikis et al proposed familial predisposition of the tumor with possibly an autosomal dominant mode of inheritance[55, 67]. Future studies with larger cohorts are needed to verify the findings.

\section{Conclusion}

Cerebellar liponeurocytomas (CLPNs) are very rare brain tumors. It usually occurred in adults with no gender predominance. Although they have favorable clinical prognosis, the recurrence is relatively high. GTR should be the first choice and close follow-up is necessary. Postoperative radiotherapy could not improve PFS in this study. A larger cohort is needed to verify our findings.

\section{Declarations}

\section{Funding}

This study was funded by Multicenter clinical big data study and multi-path tumorigenesis mechanisms and precision treatment research on brainstem glioma (JINGYIYAN2018-7) and Special Fund of the Pediatric Medical Coordinated Development Center of Beijing Hospitals Authority (XTYB201822).

\section{Conflicts of interest}

All authors declared that there were no conflicts of interest to be disclosed.

\section{Availability of data and material}

The datasets generated during the current study are available from the corresponding author on reasonable request.

\section{Code availability}

Not applicable

\section{Ethics approval}

This study was approved by the human research ethics committee of Beijing Tiantan Hospital. The written informed consent was obtained from the subjects.

\section{Consent to participate}

All patients signed an informed consent form

\section{Consent for publication}

Written informed consent for publication was obtained from all participants.

\section{Authors' contributions}

Writing, original draft, Conceptualization: Pengcheng Zuo

Statistical analysis: Tao Sun, Guocan Gu, Xiaoou Li,

Literature review: Zhuang Jiang, Changcun Pan, Cheng Xu

Methodology, Resources: Zhen Wu, Junting Zhang

Review, editing, Supervision: Liwei Zhang

\section{References}

1. Abuzneid YS, Alzeerelhouseini HIA, Shkokani S, Aqel W, Aldarawish A (2021) Cerebellar liponeurocytoma, a rare tumor: Case report and review of the literature International journal of surgery case reports 82: 105937

2. Aker FV, Ozkara S, Eren P, Peker O, Armağan S, Hakan T (2005) Cerebellar liponeurocytoma/lipidized medulloblastoma J Neurooncol 71: 53-59

3. Akhaddar A, Zrara I, Gazzaz M, El Moustarchid B, Benomar S, Boucetta M (2003) Cerebellar liponeurocytoma (lipomatous medulloblastoma) Journal of neuroradiology = Journal de neuroradiologie 30: 121-126

4. Al-Umran MR, Al-Umran SR, Arab AF, Dababo MA, Alotaibi FA (2021) Lateral ventricular liponeurocytoma: Review of literature and case illustration Neuro-Chirurgie 
5. Alkadhi H, Keller M, Brandner S, Yonekawa Y, Kollias SS (2001) Neuroimaging of cerebellar liponeurocytoma. Case report J Neurosurg 95: $324-331$

6. Anghileri E, Eoli M, Paterra R, Ferroli P, Pollo B, Cuccarini V, Maderna E, Tringali G, Saini M, Salsano E, Finocchiaro G (2012) FABP4 is a candidate marker of cerebellar liponeurocytomas J Neurooncol 108: 513-519

7. Bechtel JT, Patton JM, Takei Y (1978) Mixed mesenchymal and neuroectodermal tumor of the cerebellum Acta neuropathologica 41: 261-263

8. Beizig N, Ziadi S, Ladib M, Mokni M (2013) Cerebellar liponeurocytoma: case report Neuro-Chirurgie 59: 39-42

9. Ben Nsir A, Ben Said I, Hammami N, Sebai R, Jemel H (2014) Cerebellar liponeurocytoma with extracranial extension: case report Neurologia i neurochirurgia polska 48: 458-462

10. Ben Nsir A, Thai QA, Boubaker A, Jemel H (2018) Reversible "hemiparkinsonism" following surgery for a lateral ventricle liponeurocytoma in a 24-year old student Neurology India 66: S145-s149

11. Börekci A, Kuru Bektaşoğlu P, Ramazanoğlu AF, Gürer B, Çelikoğlu E (2018) Central liponeurocytoma as a clinical entity Neurologia i neurochirurgia polska 52: 670-676

12. Buccoliero AM, Caldarella A, Bacci S, Gallina P, Taddei A, Di Lorenzo N, Romagnoli P, Taddei GL (2005) Cerebellar liponeurocytoma: morphological, immunohistochemical, and ultrastructural study of a relapsed case Neuropathology : official journal of the Japanese Society of Neuropathology 25: 77-83

13. Cacciola F, Conti R, Taddei GL, Buccoliero AM, Di Lorenzo N (2002) Cerebellar liponeurocytoma. Case report with considerations on prognosis and management Acta Neurochir (Wien) 144: 829-833

14. Cai J, Li W, Du J, Xu N, Gao P, Zhou J, Li X (2018) Supratentorial intracerebral cerebellar liponeurocytoma: A case report and literature review Medicine (Baltimore) 97: e9556

15. Chakraborti S, Mahadevan A, Govindan A, Yasha TC, Santosh V, Kovoor JM, Ramamurthi R, Alapatt JP, Hedge T, Shankar SK (2011) Supratentorial and cerebellar liponeurocytomas: report of four cases with review of literature J Neurooncol 103: 121-127

16. Châtillon CE, Guiot MC, Roberge D, Leblanc R (2009) Cerebellar liponeurocytoma with high proliferation index: treatment options The Canadian journal of neurological sciences Le journal canadien des sciences neurologiques 36: 658-661

17. Chiaramonte C, Rabaste S, Jacquesson T, Meyronet D, Cotton F, Jouanneau E, Berhouma M (2018) Liponeurocytoma of the Cerebellopontine Angle World Neurosurg 112: 18-24

18. Chung SB, Suh YL, Lee JI (2012) Cerebellar liponeurocytoma with an unusually aggressive histopathology : case report and review of the literature Journal of Korean Neurosurgical Society 52: 250-253

19. Davis DG, Wilson D, Schmitz M, Markesbery WR (1993) Lipidized medulloblastoma in adults Human pathology 24: $990-995$

20. den Hollander J, Schlegel J, Zimmer C (2011) [A rare case of supratentorial liponeurocytoma, in vivo diagnosis with MR spectroscopy] RoFo :

Fortschritte auf dem Gebiete der Rontgenstrahlen und der Nuklearmedizin 183: 974-975

21. Deora H, Prabhuraj AR, Saini J, Yasha TC, Arimappamagan A (2019) Cerebellar Liponeurocytoma: A Rare Fatty Tumor and its Literature Review J Neurosci Rural Pract 10: 360-363

22. Dey S, Chaudhury MK, Basu SK, Chaudhury K, Chatterjee A, Manna AK, Dutta SK (2013) Photoclinic. Cerebellar liponeurocytoma Archives of Iranian medicine 16: 199-200

23. Ellison DW, Zygmunt SC, Weller RO (1993) Neurocytoma/lipoma (neurolipocytoma) of the cerebellum Neuropathology and applied neurobiology 19: 95-98

24. Elshihabi S, Husain M, Linskey M (2003) Lipomatous medulloblastoma: a rare adult tumor variant with a uniquely favorable prognosis Surgical neurology 60: 566-570

25. Fung KM, Fang W, Norton RE, Torres N, Chu A, Langford LA (2003) Cerebellar central liponeurocytoma Ultrastructural pathology 27: $109-114$

26. Gembruch O, Junker A, Ahmadipour Y, Sure U, Lemonas E (2018) Cerebellar liponeurocytoma - a rare entity: a case report Journal of medical case reports 12: 170

27. Gembruch O, Junker A, Mönninghoff C, Ahmadipour Y, Darkwah Oppong M, Sure U, El Hindy N, Lemonas E (2018) Liponeurocytoma: Systematic Review of a Rare Entity World Neurosurg 120: 214-233

28. George DH, Scheithauer BW (2001) Central liponeurocytoma The American journal of surgical pathology 25: $1551-1555$ 
29. Giangaspero F, Cenacchi G, Roncaroli F, Rigobello L, Manetto V, Gambacorta M, Allegranza A (1996) Medullocytoma (lipidized medulloblastoma). A cerebellar neoplasm of adults with favorable prognosis The American journal of surgical pathology 20: 656-664

30. Guan JT, Geng YQ, Cheng Y, Guo YL, Wu RH (2012) Magnetic resonance imaging of cerebellar liponeurocytoma. A case report and review of the literature The neuroradiology journal 25: 331-336

31. Gupta K, Salunke P, Kalra I, Vasishta RK (2011) Central liponeurocytoma: case report and review of literature Clinical neuropathology 30 : $80-85$

32. Hamzaoglu V, Ozalp H, Karatas D, Esen K, Gurses I, Dagtekin A, Avci E (2018) Clinical course of the untreated calcified big cerebellar liponeurocytoma Journal of surgical case reports 2018: rjy316

33. Hermann B, Woznica M, Kloc W, Borkowski P, Libionka W, Izycka-Swieszewska E (2017) Cerebellar liponeurocytoma with atypical histological features - a rare example of a glioneuronal tumor Folia neuropathologica 55: 227-234

34. Hirono S, Gao Y, Matsutani T, Ikeda Jl, Yokoo H, Iwadate Y (2021) Metabolic, immunohistochemical, and genetic profiling of a cerebellar liponeurocytoma with spinal dissemination: a case report and review of the literature Brain tumor pathology 38: 257-262

35. Horstmann S, Perry A, Reifenberger G, Giangaspero F, Huang H, Hara A, Masuoka J, Rainov NG, Bergmann M, Heppner FL, Brandner S, Chimelli L, Montagna N, Jackson T, Davis DG, Markesbery WR, Ellison DW, Weller RO, Taddei GL, Conti R, Del Bigio MR, González-Cámpora R, Radhakrishnan VV, Söylemezoglu F, Uro-Coste E, Qian J, Kleihues P, Ohgaki H (2004) Genetic and expression profiles of cerebellar liponeurocytomas Brain pathology (Zurich, Switzerland) 14: 281-289

36. Jackson TR, Regine WF, Wilson D, Davis DG (2001) Cerebellar liponeurocytoma. Case report and review of the literature J Neurosurg 95: 700-703

37. Jenkinson MD, Bosma JJ, Du Plessis D, Ohgaki H, Kleihues P, Warnke P, Rainov NG (2003) Cerebellar liponeurocytoma with an unusually aggressive clinical course: case report Neurosurgery 53: 1425-1427; discussion 1428

38. Kachhara R, Bhattacharya RN, Nair S, Radhakrishnan VV (2003) Liponeurocytoma of the cerebellum-a case report Neurology India 51: 274-276

39. Kakkar A, Sable M, Suri V, Sarkar C, Garg A, Satyarthee GD, Sharma MC (2015) Cerebellar Liponeurocytoma, an Unusual Tumor of the Central Nervous System-Ultrastructural Examination Ultrastructural pathology 39: 419-423

40. Karabagli P, Sav A, Pamir N (2014) Does "cerebellar liponeurocytoma" always reflect an expected site? An unusual case with a review of the literature Folia neuropathologica 52: 101-105

41. Konovalov AN, Konovalov NA, Pronin IN, Shishkina LV, Zolotova LI, Yakovlenko YG, Korolishin VA, Onoprienko RA, Timonin SY (2015) Multiple primary liponeurocytoma of the central nervous system Zhurnal voprosy neirokhirurgii imeni N N Burdenko 79: 87-96

42. Kuchelmeister K, Nestler U, Siekmann R, Schachenmayr W (2006) Liponeurocytoma of the left lateral ventricle-case report and review of the literature Clinical neuropathology 25: 86-94

43. Limaiem F, Bellil S, Chelly I, Bellil K, Mekni A, Jemel H, Haouet S, Zitouna M, Kchir N (2009) Recurrent cerebellar liponeurocytoma with supratentorial extension The Canadian journal of neurological sciences Le journal canadien des sciences neurologiques 36: 662-665

44. Louis DN, Perry A, Reifenberger G, von Deimling A, Figarella-Branger D, Cavenee WK, Ohgaki H, Wiestler OD, Kleihues P, Ellison DW (2016) The 2016 World Health Organization Classification of Tumors of the Central Nervous System: a summary Acta neuropathologica 131: 803-820

45. Louis DN, Perry A, Wesseling P, Brat DJ, Cree IA, Figarella-Branger D, Hawkins C, Ng HK, Pfister SM, Reifenberger G, Soffietti R, von Deimling A, Ellison DW (2021) The 2021 WHO Classification of Tumors of the Central Nervous System: a summary Neuro-oncology 23: 1231-1251

46. Montagna N, Moreira D, Vaz LC, Reis M (2002) Cerebellar liponeurocytoma: a newly recognized clinico-pathological entity Arquivos de neuropsiquiatria 60: 725-729

47. Nzegwu MA, Ohegbulam S, Ndubuisi C, Okwunodulu O, Okorie E, Nkwerem S, Okonkwo O, Aniume O, Nnamani S, Nwokoro O, Eni A, Nwideyi I, Nzegwu V (2016) Cerebellar Liponeurocytoma: A Novel Report from Nigeria in a 6-Year-Old Girl, and Review of Literature Rare tumors 8: 6240

48. Orlandi A, Marino B, Brunori M, Greco R, Spagnoli LG (1997) Lipomatous medulloblastoma Clinical neuropathology 16: 175-179

49. Oudrhiri MY, Raouzi N, El Kacemi I, El Fatemi N, Gana R, Maaqili MR, Bellakhdar F (2014) Understanding cerebellar liponeurocytomas: case report and literature review Case reports in neurological medicine 2014: 186826

50. Owler BK, Makeham JM, Shingde M, Besser M (2005) Cerebellar liponeurocytoma J Clin Neurosci 12: 326-329

51. Pankaj R, Jindal A, Banerjee AK (2010) Liponeurocytoma of lateral ventricle Neurology India 58: 805-806 
52. Pasquale G, Maria BA, Vania P, Gastone P, Nicola DL (2009) Cerebellar liponeurocytoma: an updated follow-up of a case presenting histopathological and clinically aggressive features Neurology India 57: 194-196

53. Patel N, Fallah A, Provias J, Jha NK (2009) Cerebellar liponeurocytoma Canadian journal of surgery Journal canadien de chirurgie 52: E117-e119

54. Pelz D, Khezri N, Mainprize T, Phan N, Keith J, Bilbao J, Aviv RI, Tsao M, Symons SP (2013) Multifocal cerebellar liponeurocytoma The Canadian journal of neurological sciences Le journal canadien des sciences neurologiques 40: 870-872

55. Pikis S, Fellig Y, Margolin E (2016) Cerebellar liponeurocytoma in two siblings suggests a possible familial predisposition J Clin Neurosci 32 : $154-156$

56. Radke J, Gehlhaar C, Lenze D, Capper D, Bock A, Heppner FL, Jödicke A, Koch A (2015) The evolution of the anaplastic cerebellar liponeurocytoma: case report and review of the literature Clinical neuropathology 34: 19-25

57. Radner H, Blümcke I, Reifenberger G, Wiestler OD (2002) [The new WHO classification of tumors of the nervous system 2000. Pathology and genetics] Der Pathologe 23: 260-283

58. Rajesh LS, Vasishta RK, Chhabra R, Banerjee AK (2003) Case report: central liponeurocytoma Neuropathology and applied neurobiology 29: 511-513

59. Ruiz Ginés JA, Ruiz Ginés M, Gonzáles Sejas AG, Alvarez Salgado JA, Belinchón de Diego JM, Cabada Del Río A, González-Llanos Fernández de Mesa F, Herguido Bóveda MJ, Hidalgo Herrera V, Ortega Martínez R, Hernández Moneo JL (2014) [Liponeurocytoma in the left lateral ventricle. Presentation of the first case reported in Spain and literature review] Neurocirugia (Asturias, Spain) 25: 183-188

60. Scoppetta TL, Brito MC, Prado JL, Scoppetta LC (2015) Multifocal cerebellar liponeurocytoma Neurology 85: 1912

61. Sivaraju L, Aryan S, Ghosal N, Hegde AS (2017) Cerebellar liponeurocytoma presenting as multifocal bilateral cerebellar hemispheric mass lesions Neurology India 65: 422-424

62. Soylemezoglu F, Soffer D, Onol B, Schwechheimer K, Kleihues P (1996) Lipomatous medulloblastoma in adults. A distinct clinicopathological entity The American journal of surgical pathology 20: 413-418

63. Taddei GL, Buccoliero AM, Caldarella A, Conti R, Di Lorenzo N, Cacciola F, Franchi A (2001) Cerebellar liponeurocytoma: immunohistochemical and ultrastructural study of a case Ultrastructural pathology 25: 59-63

64. Takami H, Mukasa A, Ikemura M, Shibahara J, Takahashi M, Momose T, Saito N (2015) Findings from positron emission tomography and genetic analyses for cerebellar liponeurocytoma Brain tumor pathology 32: 210-215

65. Tucker A, Boon-Unge K, McLaughlin N, Ibrahim H, Rao N, Martin N, Everson R, Khanlou N (2017) Cerebellar Liponeurocytoma: Relevant Clinical Cytogenetic Findings Journal of pathology and translational medicine 51: 335-340

66. Valéry CA, Sakka LJ, Poirier J (2004) Problematic differential diagnosis between cerebellar liponeurocytoma and anaplastic oligodendroglioma British journal of neurosurgery 18: 300-303

67. Wolf A, Alghefari H, Krivosheya D, Staudt MD, Bowden G, Macdonald DR, Goobie S, Ramsay D, Hebb MO (2016) Cerebellar liponeurocytoma: a rare intracranial tumor with possible familial predisposition. Case report J Neurosurg 125: 57-61

68. Xu L, Du J, Wang J, Fang J, Liu Z, He Y, Li G (2017) The clinicopathological features of liponeurocytoma Brain tumor pathology 34: 28-35

69. Xu N, Cai J, Du J, Yang R, Zhu H, Gao P, Zhou J, Li X (2017) Clinical features and prognosis for intraventricular liponeurocytoma Oncotarget 8: 6264162647

\section{Figures}

\section{Figure 1}

Magnetic resonance imaging (MRI) shows a heterogeneous T1WI (A) and heterogeneous T2WI (B) solid mass with significant enhancement (C) located at right cerebellum. Postoperative MRI revealed the tumor was resected totally (D-F). G: Histopathological examination revealed the typical morphology of cerebellar liponeurocytoma. Some fat foci are dispersed within atypical tumor cells $(\mathrm{H} \& \mathrm{E}, \times 200)$.

展

\section{Figure 2}

Magnetic resonance imaging (MRI) shows a heterogeneous T1WI (A) and heterogeneous T2WI (B) cystic-solid mass with no enhancement (C) located at lateral ventricle. Postoperative MRI revealed the tumor was resected totally (D-F). G: H\&E stained section showed monotonous tumor cells with round 
nuclei and clear cytoplasm with sparse lipomatous cells $(H \& E, \times 200)$.
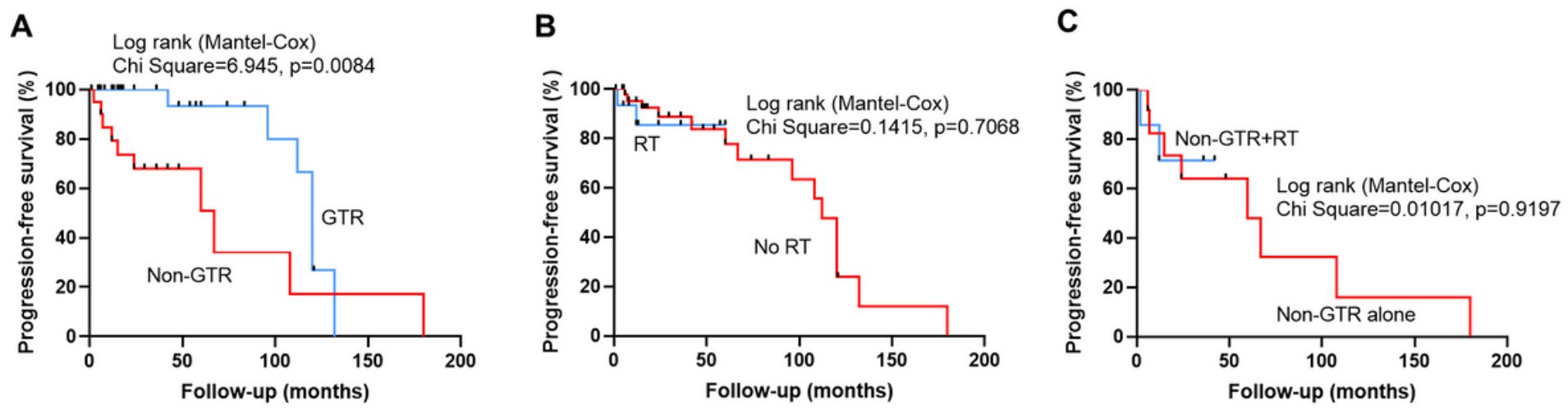

\section{Figure 3}

Kaplan-Meier survival curves showing PFS of the pooled cohort divided into GTR and Non-GTR groups (A) and RT and No RT groups (B). Survival curve analysis displaying PFS in non-GTR group between radiotherapy and no radiotherapy (C). 